\title{
Distribution of Peripheral Lymphocyte Populations in Primary Sjögren's Syndrome Patients
}

\author{
Gintaras Sudzius, ${ }^{1}$ Diana Mieliauskaite, ${ }^{2}$ Almantas Siaurys, ${ }^{1}$ Rita Viliene, \\ Irena Butrimiene, ${ }^{2,3}$ Dainius Characiejus, ${ }^{1,4}$ and Irena Dumalakiene ${ }^{1,5}$ \\ ${ }^{1}$ Department of Immunology, State Research Institute Centre for Innovative Medicine, LT-08409 Vilnius, Lithuania \\ ${ }^{2}$ Department of Innovative Diagnostic Treatment and Health Monitoring Technology, State Research Institute Centre for \\ Innovative Medicine, LT-01102 Vilnius, Lithuania \\ ${ }^{3}$ Faculty of Medicine, Vilnius University, LT-03101 Vilnius, Lithuania \\ ${ }^{4}$ Department of Pathology, Forensic Medicine and Pharmacology, Faculty of Medicine, Vilnius University, LT-03101 Vilnius, Lithuania \\ ${ }^{5}$ Department of Chemistry and Bioengineering, Faculty of Fundamental Sciences, Vilnius Gediminas Technical University, \\ LT-10223 Vilnius, Lithuania
}

Correspondence should be addressed to Irena Dumalakiene; i.dumalakiene@imcentras.lt

Received 17 September 2014; Revised 21 December 2014; Accepted 12 January 2015

Academic Editor: Guixiu Shi

Copyright (C) 2015 Gintaras Sudzius et al. This is an open access article distributed under the Creative Commons Attribution License, which permits unrestricted use, distribution, and reproduction in any medium, provided the original work is properly cited.

Purpose of this study was to evaluate the lymphocyte populations' distribution changes in peripheral blood of patients with primary Sjögren's syndrome (pSS). Lymphocyte populations' distribution changes in peripheral blood of pSS patients were investigated in 52 patients with pSS and in 28 healthy controls by flow cytometry. We found decreased absolute count of $\mathrm{CD}^{+} \mathrm{T}$ cell population in pSS patients. Analysis of $\mathrm{CD}^{+} \mathrm{T}$ cell population showed significant proportion and absolute count differences in pSS patient's blood with SSA/SSB antibodies (Abs) in comparison to controls. No significant differences were observed analyzing CD $4^{+}$and CD8 ${ }^{+}$ Treg subpopulation. Proportion and absolute counts of Th17 cells were significantly lower in pSS patient's blood. Absolute counts of $\mathrm{CD}^{+} \mathrm{T}$ cells were significantly lower in pSS patients in comparison to controls and also impaired proportion and absolute counts of $\mathrm{CD}^{+}$subpopulations according to $\mathrm{CD} 27^{+}$and $\mathrm{CD} 57^{+}$were observed. Absolute counts of NKT and NK cells were decreased in pSS with Abs. B cells proportion was increased only in blood of pSS with Abs. Lymphocyte distribution impairment can be due to genetically determined lymphopenia or lymphocyte migration from periphery to inflammatory sites or/and increased susceptibility to apoptosis.

\section{Introduction}

Primary Sjögren's syndrome (pSS) is a systemic autoimmune disorder that affects secretory organs and is characterized by ocular and mouth dryness, fatigue, and pain, as well as extra-glandular manifestations that reveal the severity of this disorder $[1,2]$. Patients with pSS also present broad spectrum analytical features (cytopenias, hypergammaglobulinemia, and cryoglobulins). Biological signatures of the disease are B-lymphocyte activation, which could be triggered by the dysregulation of B-cell activating factor (BAFF) [1]. It is suggested that BAFF is influential in driving antibody production in autoimmune diseases [2]. One of the objective classification criteria for pSS is serum SSA/SSB antibodies (Abs) [2].
Recent research studies suggest that these antibodies may also be the biomarkers of disease activity [3]. Some studies indicate that anti-SSA/SSB seropositive patients have the increased amount of B-cell activation markers, such as BAFF, free immunoglobulin light chain, beta-2 microglobulin, and IgG [3-7]. Thus, the spectrum of the disease ranges widely from minimal local symptoms of the eyes and oral mucosa to systemic involvement and development of malignant lymphoma; the latter are being the most worrisome complication of pSS [2]. Pathophysiology of Sjögren's syndrome is not yet fully understood. Recently, much attention has been focused on the relationship between innate responses and subsequent activation of specific adaptive-immunity in an attempt to understand subsequent immune dysregulation 
TABLE 1: Clinical and serological characteristics of pSS patients.

\begin{tabular}{|c|c|c|c|}
\hline Features & $\begin{array}{l}{ }^{1} \mathrm{pSS} \mathrm{Abs}^{-} \\
(n=29)\end{array}$ & $\begin{array}{l}{ }^{2} \mathrm{pSS} \mathrm{Abs}{ }^{+} \\
(n=23)\end{array}$ & $\begin{array}{c}P^{*} \\
\mathrm{I}-\mathrm{II} \\
\end{array}$ \\
\hline Age, mean $\pm \mathrm{SD}$ years & $56 \pm 12$ & $56 \pm 13$ & 0.873 \\
\hline Schirmer's $I$ test $(\mathrm{mm} / 5 \mathrm{~min})$, mean $\pm \mathrm{SD}$ & $3.17 \pm 1.20$ & $1.25 \pm 1.12$ & $<0.0001$ \\
\hline Unstimulated salivary flow ( $\mathrm{mL} / 15 \mathrm{~min})$, mean \pm SD & $1.22 \pm 0.20$ & $0.83 \pm 0.39$ & 0.002 \\
\hline $\begin{array}{l}\text { Biopsy focus score } \\
\text { (number of lymphocytic foci } / 4 \mathrm{~mm}^{2} \text { ), mean (min/max) }\end{array}$ & $1.17(1 / 2)$ & $2.40(1 / 3)$ & $<0.0001$ \\
\hline Anti-SSA ${ }^{+}, n(\%)$ & $0(0)$ & $6(26)$ & \\
\hline Anti-SSB ${ }^{+}, n(\%)$ & $0(0)$ & $2(9)$ & \\
\hline BAFF, mean $\pm \mathrm{SD}, \mathrm{ng} / \mathrm{mL}$ & $4230(1748)$ & $5014(2518)$ & 0.187 \\
\hline Anti-SSA/SSB ${ }^{+}, n(\%)$ & $0(0)$ & $15(65)$ & \\
\hline ESSPRI, mean $(\min / \max )$ & $8.39(6 / 10)$ & $9.1(7 / 10)$ & 0.075 \\
\hline ESSDAI, mean (min/max) & $24.83(21 / 30)$ & $33.50(27 / 39)$ & $<0.0001$ \\
\hline
\end{tabular}

${ }^{*}$ Mann-Whitney test. ${ }^{1}$ pSS $\mathrm{Abs}^{-}$: pSS patients without anti-SSA/SSB; ${ }^{2}$ pSS Abs ${ }^{+}$: pSS patients with anti-SSA and/or anti-SSB. ESSDAI: EULAR Sjögren's syndrome disease activity index; ESSPRI: EULAR Sjögren’s syndrome patient reported index.

[8-10]. Specific cytotoxic lymphocyte populations can lead to the formation of autoimmune diseases, whereas suppressive/regulatory cell populations may lead to suppression of autoimmunity and disease remission [11, 12]. However, the pathological role of T cells in pSS remains to be elucidated.

The aim of the study was to perform a detailed quantitative analysis of peripheral blood $\mathrm{CD}^{+}$and $\mathrm{CD}^{+} \mathrm{T}$ lymphocyte subpopulations in patients with Sjögren's syndrome with special emphasis on Treg, Th17, NKT lymphocytes, NK cells, and B cells and expression of CD57 and CD27 markers on $\mathrm{CD} 8^{\text {high }}$ lymphocytes.

\section{Patients and Methods}

2.1. Patients. In total, 52 patients with pSS and 28 healthy controls were recruited at the State Research Institute Center for Innovative Medicine for this study. Patients with pSS were grouped in two groups: pSS $\mathrm{Abs}^{-}$group, 29 without antiSSA and/or anti-SSB Abs, and pSS $\mathrm{Abs}^{+}$group, 23 patients with anti-SSA and/or anti-SSB Abs. The average age of the patients groups and healthy controls was accordingly: $57 \pm 13$ years, $56 \pm 13$ years, and $53 \pm 11$ years. The majority of enrolled patients in our study were Lithuanian women. Only 1 Lithuanian man ( 1 in pSS $\mathrm{Abs}^{+}$group) was enrolled in pSS group. Nobody of the control group had connective tissue diseases, anti-SSA or anti-SSB Abs. Primary SS was diagnosed according to American-European Consensus Group Classification criteria for Sjögren's syndrome [2]. All patients underwent serologic evaluations, which included test for the presence of antibodies against SSA and SSB, Schirmer's I test, unstimulated whole salivary flow test, and histology of minor salivary glands. Disease activity was assessed using EULAR Sjögren's syndrome disease activity index (ESSDAI) [13] and EULAR Sjögren's syndrome patient reported index (ESSPRI) [14]. The characteristics of the pSS patients included in the study are summarized in Table 1. Informed and written consent was obtained from all participants of this study. The study has been approved by the Lithuanian Bioethics Committee (no. 158200-03-299-73).
2.2. Lymphocyte Populations' Proportion and Absolute Counts Determination in Peripheral Blood. Blood samples were collected from heparinized venous blood. Absolute counts of white blood cells (WBC) were determined with a haemocytometer and used for calculation of absolute numbers of lymphocyte populations (numbers of cells/ $\mu \mathrm{L}$ peripheral blood). For cell surface staining, the following mAbs were used: antiCD3 FITC (Exbio, Czech); anti-CD4 PerCP (BD, USA); antiCD8-PerCP (BD); anti-CD-16+56-PE (Exbio, Czech); antiCD-19 PerCP (Exbio, Czech); anti-CD57 FITC (BD, USA); and anti-CD27-APC (Exbio, Czech). For isotype controls staining, mouse anti-IgG1-FITC (BD, USA), IgG1-PerCP (BD, USA), and IgG2a-PE (BD, USA) were used. Staining was performed at room temperature for $30 \mathrm{~min}$. Cell staining was followed by red blood cell lysis using Pharm Lyse (BD, USA) lysing solution for $15 \mathrm{~min}$ at room temperature in the dark. Leukocytes were then centrifuged $(500 \mathrm{~g}$ for $10 \mathrm{~min}$ ) and washed two times with CellWash (BD, USA) and resuspended in FBS (BD, USA). Samples were examined immediately after staining without fixation.

For the evaluation of intracellular cytokine IL-17A of $\mathrm{CD}^{+} \mathrm{T}$ cells, $1 \mathrm{~mL}$ of whole heparinized blood was diluted $1: 2$ in RPMI-1640 supplemented with $80 \mathrm{mg} / \mathrm{L}$ gentamycin and $2 \mathrm{nM}$ glutamine. Cells were stimulated using $50 \mathrm{ng} / \mathrm{mL}$ phorbol-myristate-acetate (Sigma Aldrich, St. Louis, MO, USA) and $1 \mathrm{ng} / \mathrm{mL}$ ionomycin (Sigma Aldrich) in the presence of $0.7 \mu \mathrm{L} / \mathrm{mL}$ monensin (GolgiStop (BD, USA)) for $4.5 \mathrm{~h}$ at $37^{\circ} \mathrm{C}$ in an atmosphere containing $5 \% \mathrm{CO}_{2}$. Unstimulated cells served as controls. Following stimulation, cells were stained for CD4 for $30 \mathrm{~min}$ at room temperature. Cell staining was followed by red blood cell lysis using Pharm Lyse (BD, USA) lysing solution for $15 \mathrm{~min}$ at room temperature in the dark. Leucocytes were then centrifuged (at $500 \mathrm{~g}$ for $10 \mathrm{~min}$ ) and washed two times with CellWash (BD). Then, cells were fixed and permeabilized with Cytofix/Cytoperm (BD, USA) solution for $20 \mathrm{~min}$, washed two times with Perm/Wash (BD, USA) solution, and incubated further for $30 \mathrm{~min}$ in the dark with the specific mAbs anti-IL17A APC (BD, USA) and isotypic control anti-IgG1 APC (BD, USA). Following the 
incubation with mAbs, the cells were washed two times with Perm/Wash solution and resuspended in FBS (BD, USA).

For the evaluation of intracellular FoxP3 marker of CD $4^{+}$ and $\mathrm{CD}^{+} \mathrm{T}$ cells, cells were stained with anti-CD4 PerCP (BD, USA), anti-CD25 FITC (Exbio, Czech), and anti-CD8PerCP (BD, USA) for $30 \mathrm{~min}$ at room temperature. Cell staining was followed by red blood cell lysis using Pharm Lyse (BD, USA) solution for $15 \mathrm{~min}$ at room temperature in the dark. Leucocytes were then centrifuged (at $500 \mathrm{~g}$ for $10 \mathrm{~min}$ ) and washed two times with CellWash (BD, USA). Then, cells were fixed and permeabilized with Cytofix/Cytoperm (BD, USA) solution for $20 \mathrm{~min}$, washed two times with Perm/Wash (BD, USA) solution, and incubated further for $30 \mathrm{~min}$ in the dark with the specific mAbs anti-FoxP3-PE (BD, USA) and isotypic controls anti-IgG1-FITC (BD, USA), IgG1-PerCP (BD, USA), and IgG2a-PE (BD, USA). Following the incubation with $\mathrm{mAbs}$, the cells were washed two times with Perm/Wash (BD, USA) solution and resuspended in FBS (BD, USA). Lymphocytes were gated and separated based on their morphological properties.

Flow cytometry was performed on FACSCalibur flow cytometer (BD Biosciences, San Jose, CA, USA) calibrated with CaliBRITE beads (BD Biosciences, San Jose, CA, USA) using CELL-Quest software (BD Biosciences, San Jose, CA, USA). Data for each sample were acquired until 100,000 leukocytes were analyzed.

2.3. Determination of BAFF Level in Serum. Serum samples were analyzed using commercial BAFF, Soluble (human) ELISA Kit (hypersensitive) (AdipoGen, Switzerland). From collected blood samples, serum was separated and stored at $-80^{\circ} \mathrm{C}$ until analysis. Serum dilutions and enzyme-linked immunoassay was carried out in the strict accordance with the manufacturer's instructions and sets recommendations. The results were evaluated by spectrophotometer (BioTek Instruments, USA). The concentrations of analytes in ELISA assays were quantified using standard curves. A regression analysis was performed to derive an equation that was then used to predict the concentration of the unknown samples with Gen5 Microplate Data Collection \& Analysis Software (BioTek Instruments, USA). The results are shown in Table 1.

2.4. Statistics. Statistical differences were analyzed using the Mann-Whitney $U$ test. Correlations were assessed by the Spearman's rank test using standard program GraphPad Prism 5.0 software (GraphPad Software, San Diego, CA, USA). $P$ values less than 0.05 were considered significant.

\section{Results}

3.1. Main Lymphocyte Populations. We found that absolute count of $\mathrm{CD}^{+} \mathrm{T}$ cell population was significantly decreased in pSS patients in comparison to healthy controls. No differences were observed between pSS groups. Significant decrease of $\mathrm{CD}^{+}$cells was found in pSS Abs ${ }^{-}(P=0.027)$ and pSS $\mathrm{Abs}^{+}(P=0.0002)$ groups when compared to controls; however, no differences in the $\mathrm{CD}^{+}$cells proportion of WBC were found between pSS groups. Analysis of $\mathrm{CD}^{+} \mathrm{T}$ cell population showed significant proportion differences in pSS $\mathrm{Abs}^{+}$patient's blood when compared to pSS $\mathrm{Abs}^{-}(P=0.036)$ and control group $(P=0.0036)$. But absolute counts of $\mathrm{CD}^{+}$cells were significantly lower in both pSS groups than in control group, pSS $\operatorname{Abs}^{-}(P=0.015)$ and pSS $\mathrm{Abs}^{+}$ $(P<0.0001)$, and also absolute counts of $\mathrm{CD}^{+}$cells were significantly lower in pSS $\mathrm{Abs}^{+}$than in pSS $\mathrm{Abs}^{-}(P=0.01)$ patients' blood. No significant differences in the proportion of $\mathrm{CD}^{+} \mathrm{T}$ cell population were found between $\mathrm{pSS}$ patients and controls. But analysis of absolute counts showed significantly lower counts of CD8 ${ }^{+} \mathrm{T}$ cells in pSS $\mathrm{Abs}^{-}(P=0.014)$ and $\mathrm{pSS}$ $\operatorname{Abs}^{+}(P=0.006)$ in comparison to controls; no differences were found between pSS groups (Table 2, Figure 1). Analysis of NKT $\left(\mathrm{CD}^{+} \mathrm{CD} 16 / 56^{+}\right)$and $\mathrm{NK}\left(\mathrm{CD}^{-} \mathrm{CD} 16 / 56^{+}\right)$cells showed only decreased absolute counts in pSS $\mathrm{Abs}^{+}$group (resp., $P=0.009$ and $P=0.036$ ) in comparison to controls. Increased proportion of $\mathrm{CD}^{-} \mathrm{CD}^{+} 9^{+}$(B cells) in pSS $\mathrm{Abs}^{+}$ $(P=0.045)$ was found when compared to controls, but no differences were found analyzing absolute counts among pSS groups and controls (Table 2).

3.2. $\mathrm{CD}^{+}$Lymphocyte Subpopulations. Analysis of $\mathrm{CD} 4^{+}$ lymphocyte subpopulations according to their expression of CD25 and FoxP3 markers showed significant reduced absolute counts of $\mathrm{CD}^{+} \mathrm{CD}^{2} 5^{+}(P=0.036)$ and $\mathrm{CD} 4^{+}$ CD25 ${ }^{\text {low }}$ FoxP3 $(P=0.017)$ cells when comparing pSS $\mathrm{Abs}^{+}$with controls. No significant differences were observed analyzing other $\mathrm{CD}^{+}$subpopulations according to their expression of CD25 and FoxP3 markers (Table 3). Analysis of $\mathrm{CD} 4^{+} \mathrm{IL}_{-17 \mathrm{~A}^{+}}$(Th17) cells showed significant lower proportion and absolute counts of these cells in pSS patients in comparison to control group's results (Figure 2). Proportion was significantly altered in pSS $\mathrm{Abs}^{-}(P=0.0003)$ and pSS $\mathrm{Abs}^{+}(P=0.004)$, and also absolute counts of Th17 cell were significantly lower in pSS $\mathrm{Abs}^{-}(P<0.0001)$ and pSS $\mathrm{Abs}^{+}$ $(P<0.0001)$ patients' blood in comparison to controls. No significant differences were found analyzing proportion and absolute counts of this subpopulation between pSS groups (Table 3, Figure 1).

3.3. $C D 8^{+}$Lymphocyte Subpopulations. CD $8^{\text {high }}$ lymphocyte population was differentiated to subpopulations according to the markers CD57 and CD27 that defines replicative senescence (Figure 1). Analysis of $\mathrm{CD} 8{ }^{\text {high }} \mathrm{CD} 57^{+} \mathrm{CD} 27^{-}$subpopulation showed no differences in proportion and absolute counts among pSS and control groups. In pSS patients with Abs, we observed significantly increased proportion $(P=0.032)$ and absolute counts $(P=0.011)$ of $\mathrm{CD} 8{ }^{\text {high }} \mathrm{CD} 57^{+} \mathrm{CD} 27^{+}$subpopulation in comparison to pSS without Abs. No significant differences were found when comparing results of pSS $\mathrm{Abs}^{+}$and pSS $\mathrm{Abs}^{-}$to controls. $\mathrm{CD} 8{ }^{\text {high }} \mathrm{CD} 7^{-} \mathrm{CD} 27^{+}$population's proportion was significantly reduced only in pSS without Abs patients' blood $(P=$ 0.026 ) when compared to controls and no significant differences between pSS groups were observed. Absolute counts of this subpopulation were significantly reduced both pSS Abs ${ }^{-}$ $(P=0.0003)$ and $\mathrm{pSS} \mathrm{Abs}^{+}(P=0.005)$ in comparison to controls. Proportion of CD ${ }^{\text {high }}$ subpopulation lacking CD57 
TABLE 2: Distribution of lymphocyte populations in peripheral blood of pSS patients and controls.

\begin{tabular}{|c|c|c|c|c|c|c|}
\hline Patients & ${ }^{1}$ I-controls & ${ }^{2}$ II-pSS Abs ${ }^{-}$ & ${ }^{3}$ III-pSS Abs ${ }^{+}$ & $\begin{array}{c}P^{*} \\
\text { I-II }\end{array}$ & $\begin{array}{c}P^{*} \\
\text { I-III }\end{array}$ & $\begin{array}{c}P^{*} \\
\text { II-III }\end{array}$ \\
\hline \multicolumn{7}{|c|}{ Main lymphocyte populations } \\
\hline \multicolumn{7}{|c|}{$\mathrm{CD}^{+} \mathrm{T}$ cells } \\
\hline$\%^{4}$ & $75.36 \pm 6.93$ & $72.16 \pm 9.81$ & $73.03 \pm 8.47$ & NS & NS & NS \\
\hline A. count $t^{\#}$ & $2530 \pm 811.0$ & $2154 \pm 1133$ & $1868 \pm 1052$ & 0.027 & 0.0002 & NS \\
\hline \multicolumn{7}{|l|}{$\mathrm{CD} 4^{+} \mathrm{T}$ cells } \\
\hline$\%^{4}$ & $49.33 \pm 9.12$ & $46.20 \pm 8.49$ & $39.37 \pm 12.39$ & NS & 0.0036 & 0.036 \\
\hline A. count ${ }^{\#}$ & $1688 \pm 654.9$ & $1391 \pm 804.3$ & $1089 \pm 975.4$ & 0.015 & $<0.0001$ & 0.01 \\
\hline \multicolumn{7}{|l|}{$\mathrm{CD}^{+} \mathrm{T}$ cells } \\
\hline$\%^{4}$ & $26.73 \pm 7.29$ & $26.25 \pm 8.82$ & $29.87 \pm 11.64$ & NS & NS & NS \\
\hline A. count ${ }^{\#}$ & $939 \pm 326.4$ & $760.5 \pm 433.5$ & $690.2 \pm 259.6$ & 0.014 & 0.006 & NS \\
\hline \multicolumn{7}{|l|}{ B cells } \\
\hline$\%^{4}$ & $11.86 \pm 4.43$ & $13.82 \pm 9.13$ & $14.52 \pm 5.15$ & NS & 0.045 & NS \\
\hline A. count $^{\#}$ & $401.3 \pm 216.5$ & $351.2 \pm 197.8$ & $393.5 \pm 294.1$ & NS & NS & NS \\
\hline \multicolumn{7}{|l|}{ NK } \\
\hline$\%^{4}$ & $12.19 \pm 5.67$ & $12.99 \pm 6.84$ & $12.10 \pm 6.05$ & NS & NS & NS \\
\hline A. count ${ }^{\#}$ & $415.4 \pm 186.7$ & $365.7 \pm 210.7$ & $306.1 \pm 201.7$ & NS & 0.036 & NS \\
\hline \multicolumn{7}{|l|}{ NKT } \\
\hline$\%^{4}$ & $6.79 \pm 4.26$ & $8.44 \pm 8.51$ & $6.36 \pm 5.86$ & NS & NS & NS \\
\hline A. count ${ }^{\#}$ & $223.4 \pm 132.0$ & $206.7 \pm 168.6$ & $137.7 \pm 127.1$ & NS & 0.009 & NS \\
\hline
\end{tabular}

${ }^{1}$ I group: healthy controls; ${ }^{2}$ II group: pSS patients without anti-SSA/SSB; ${ }^{3}$ III group: pSS patients with anti-SSA and/or anti-SSB; $\%{ }^{4}$ : proportion of all CD $4^{+}$ lymphocytes; A. count ${ }^{\#}$ : absolute count of cells in $1 \mu \mathrm{L}$ of blood. ${ }^{*}$ Mann-Whitney test. NS: not significant.

and $\mathrm{CD} 27$ markers $\left(\mathrm{CD} 8^{\text {high }} \mathrm{CD} 57^{-} \mathrm{CD} 27^{-}\right)$was significantly increased only in pSS $\mathrm{Abs}^{-}$patients' blood when compared to controls. Differences in proportion or absolute counts of subpopulation expressing FoxP3 marker were not observed (Table 4).

3.4. Correlation between Cell Populations' Changes and Clinical Parameters in pSS Abs ${ }^{-}$Patients. Focus score correlated with absolute counts of $\mathrm{CD}^{+}(P=0.047, r=0.474)$, $\mathrm{CD}^{+}(P=0.033, r=0.503)$, B cell $(P=0.023, r=$ 0.532), and $\mathrm{CD}^{+} \mathrm{CD}^{-} 7^{-} \mathrm{CD} 27^{+}(P=0.016, r=0.560)$ cell populations. ESSPRI correlated with NK $(P=0.034$, $r=0.501)$. ESSDAI correlated with NK $(P=0.043, r=$ $0.482)$ and $\mathrm{CD}^{+} \mathrm{CD} 25^{\text {high }}$ FoxP3 $(P=0.047, r=0.474)$ cell absolute counts. In pSS patients without Abs, we found that Schirmer's $I$ test correlated with proportion $(P=0.033$, $r=0.504)$ and absolute counts $(P=0.015, r=0.562)$ of Th17 cells. Serum BAFF concentration correlated with proportion of $\mathrm{CD}^{+}(P=0.032, r=0.415), \mathrm{NK}(P=$ $0.009, r=0.491)$, and $\mathrm{CD} 8{ }^{\text {high }} \mathrm{CD} 57^{+} \mathrm{CD} 27^{-}(P=0.014$, $r=0.469)$ cell populations and negatively correlated with B cells $(P=0.026, r=-0.429), \mathrm{CD} 8^{\text {high }} \mathrm{CD} 57^{+} \mathrm{CD} 27^{+}$ $(P=0.036, r=-0.404)$, and $\mathrm{CD} 8^{\text {high }} \mathrm{CD} 57^{-} \mathrm{CD} 27^{+}(P=$ $0.009, r=-0.493)$. Analyzing absolute counts of cells populations observed negative correlation between BAFF and $\mathrm{CD}^{+}(P=0.025, r=-0.430)$, B cell $(P=0.007, r=$ $-0.509), \mathrm{CD}^{\text {high }} \mathrm{CD}^{+} 7^{+} \mathrm{CD} 27^{+}(P=0.028, r=-0.424)$, and $\mathrm{CD}^{\text {high }} \mathrm{CD}^{-} 7^{-} \mathrm{CD} 27^{+}(P=0.017, r=-0.454)$ cells.
3.5. Correlation between Cell Populations' Changes and Clinical Parameters in pSS Abs ${ }^{+}$Patients. Schirmer's I test correlated with proportion of $\mathrm{B}$ cells $(P=0.038, r=0.467)$ and $\mathrm{CD} 8{ }^{\text {high }} \mathrm{CD}^{-} 7^{-} \mathrm{CD} 27^{+}(P=0.006, r=0.589)$ and negatively correlated with $\mathrm{CD}^{+}(P=0.006, r=-0.590)$ and $\mathrm{CD} 8{ }^{\text {high }} \mathrm{CD}^{2} 7^{-} \mathrm{CD} 27^{-}(P=0.033, r=-0.479)$ cells. Also correlation between Schirmer's $I$ test and absolute count of $\mathrm{CD} 8{ }^{\text {high }} \mathrm{CD}^{2} 7^{-} \mathrm{CD} 27^{+}(P=0.021, r=0.512)$ and negative correlation with $\mathrm{CD} 8{ }^{\text {high }} \mathrm{CD} 57^{-} \mathrm{CD} 27^{-}(P=0.017$, $r=-0.525)$ cell counts were observed. Unstimulated salivary flow rate correlated with proportion of $\operatorname{CD}^{+}(P=0.017, r=$ $0.525)$ and Thl7 $(P=0.015, r=0.535)$ and also negatively correlated with absolute counts of $\mathrm{CD}^{+}(P=0.011, r=$ $-0.555)$ and $\mathrm{CD}^{+}(P=0.017, r=-0.526)$ cells. Focus score negatively correlated with proportion and absolute counts of $\mathrm{CD}^{\text {high }} \mathrm{CD}^{+} 7^{+} \mathrm{CD} 27^{-}$cells, respectively, $(P=0.020, r=$ $-0.517)$ and $(P=0.040, r=-0.462)$. ESSPRI correlated with proportion of $\mathrm{CD}^{+}(P=0.015, r=0.535), \mathrm{CD}^{+}$FoxP3 $(P=0.044, r=0.454)$, and $\mathrm{CD} 4^{+} \mathrm{CD} 25^{+}$FoxP3 $(P=0.041$, $r=0.461)$ cells and negatively correlated with proportion of $\mathrm{CD}^{+} \mathrm{CD}^{+} 5^{+}(P=0.026, r=-0.496)$ and $\mathrm{CD} 4^{+} \mathrm{CD} 25^{\text {high }}$ $(P=0.043, r=-0.456)$ cells. ESSDAI negatively correlated with proportion of Th17 $(P=0.001, r=-0.675)$ cells and also with absolute counts of $\mathrm{CD}^{+}(P=0.042, r=-0.459)$, Th17 $(P=0.001, r=-0.673)$, and $\mathrm{CD} 8^{\text {high }} \mathrm{CD}^{+} 7^{+} \mathrm{CD} 27^{+}(P=$ $0.028, r=-0.492)$ cells. No correlation was observed between serum BAFF concentration and cell populations changes in pSS patients with Abs. 

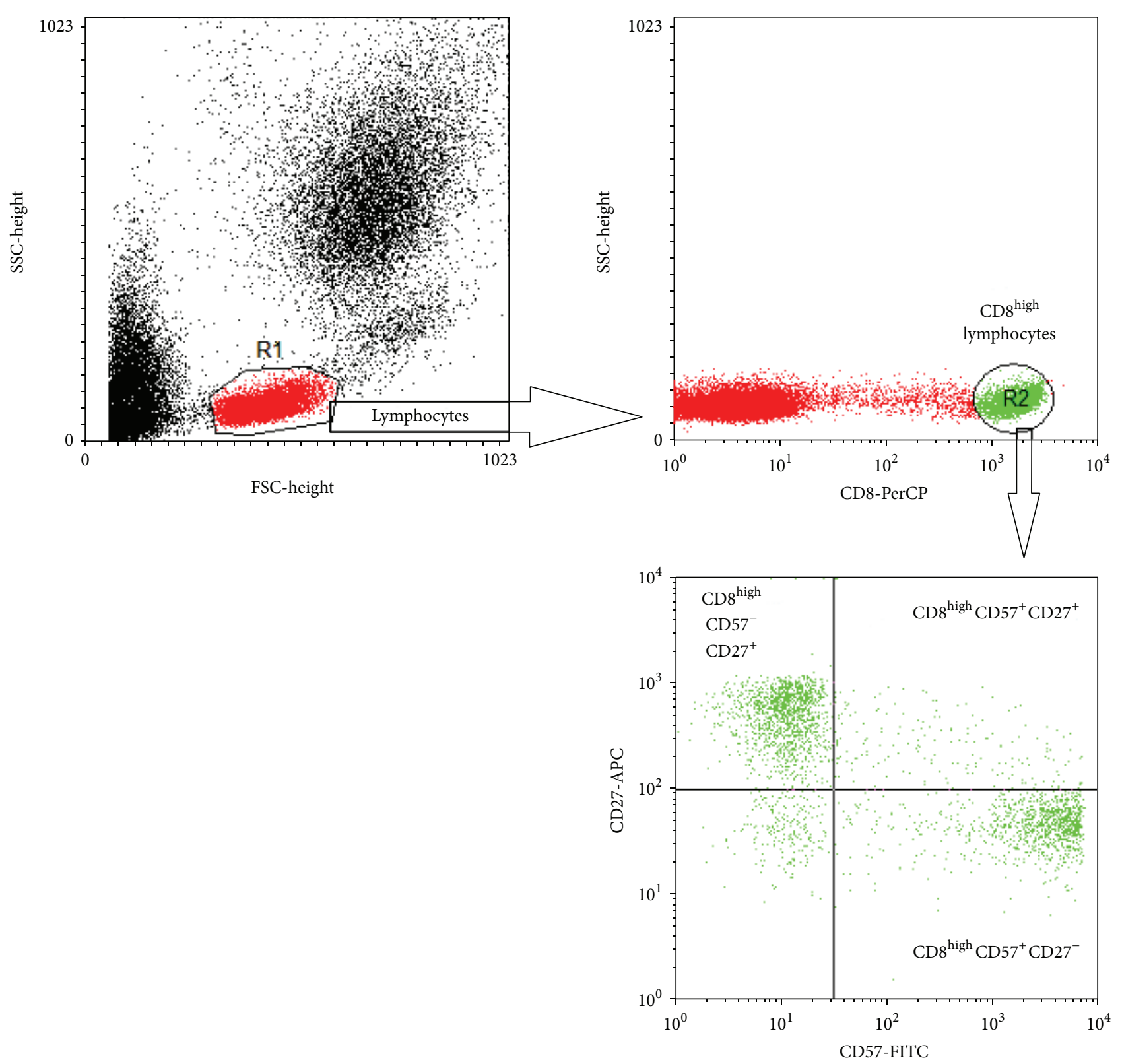

FIGURE 1: Representative dot plots. $\mathrm{CD} 8^{\text {high }}$ lymphocytes in the $\mathrm{CD} 8^{+}$subset were determined in the flow cytometric SSC/CD8-PerCP dot plot and percentages of $\mathrm{CD} 8{ }^{\text {high }} \mathrm{CD} 57^{-} \mathrm{CD} 27^{+}$lymphocytes were determined in gated $\mathrm{CD} 8^{\text {high }}$ subset in the flow cytometric CD57-FITC/CD27APC dot plot.

\section{Discussion}

Despite systemic B-cell hyperactivity, T and B cells constitute the vast majority of infiltrating mononuclear cells at the minor salivary glands inflammatory lesions of pSS, with their prevalence varying according to the severity of the infiltrates. The majority of these $\mathrm{T}$ cells are $\mathrm{CD} 4^{+}$and show an activated phenotype. $\mathrm{CD} 8^{+} \mathrm{T}$ cells with cytotoxic activity, as manifested by their expression of granzymes, constitute around $15 \%$ of infiltrating cells. T cells predominate in mild lesions, whereas in severe lesions B cells constitute the main population. The prevalence of $\mathrm{CD} 4^{+} \mathrm{T}$ cells decreases with lesion severity, whereas the prevalence of $\mathrm{CD}^{+} \mathrm{T}$ cells remains unchanged.
The prevalence of regulatory $\mathrm{T}$ cells associates with lesion severity, with the higher values to be observed at intermediate lesions. NK cells comprise a small but considerable portion of the infiltrating mononuclear cells, and their percentage correlates with the grade of the lesions $[15,16]$.

In our study, T lymphocyte identification by CD4 and CD8 markers showed a statistically significant decrease in the absolute counts of $\mathrm{CD}^{+}$and $\mathrm{CD}^{+} \mathrm{T}$ lymphocytes in the peripheral blood of pSS patients in comparison to the control group. This shows that the decline of $\mathrm{CD}^{+}$ $\mathrm{T}$ lymphocyte population in the peripheral blood of pSS patients is influenced by a decrease of both $\mathrm{CD} 4^{+}$and $\mathrm{CD} 8^{+}$ $\mathrm{T}$ lymphocyte absolute counts. The decrease of the total 
TABLE 3: Distribution of CD4 $4^{+}$lymphocyte subpopulations in peripheral blood of pSS patients and controls.

\begin{tabular}{|c|c|c|c|c|c|c|}
\hline Patients & ${ }^{1}$ I-controls & ${ }^{2} \mathrm{II}-\mathrm{pSS}$ Abs ${ }^{-}$ & ${ }^{3}$ III-pSS Abs ${ }^{+}$ & $\begin{array}{l}P^{*} \\
\text { I-II }\end{array}$ & $\begin{array}{c}P^{*} \\
\text { I-III }\end{array}$ & $\begin{array}{c}P^{*} \\
\text { II-III }\end{array}$ \\
\hline \multicolumn{7}{|c|}{$\mathrm{CD} 4^{+}$lymphocyte populations } \\
\hline \multicolumn{7}{|c|}{$\mathrm{CD} 4^{+} \mathrm{CD} 25^{+}$} \\
\hline$\%^{4}$ & $10.00 \pm 10.94$ & $9.72 \pm 6.1$ & $11.64 \pm 9.38$ & NS & NS & NS \\
\hline A. count ${ }^{\#}$ & $183.6 \pm 222.3$ & $132.7 \pm 106.0$ & $106.1 \pm 75.89$ & NS & 0.036 & NS \\
\hline \multicolumn{7}{|c|}{$\mathrm{CD} 4^{+} \mathrm{CD} 25^{\text {high }}$} \\
\hline$\%^{4}$ & $1.97 \pm 1.342$ & $2.45 \pm 1.71$ & $2.71 \pm 1.83$ & NS & NS & NS \\
\hline A. count ${ }^{\#}$ & $32.13 \pm 25.88$ & $31.81 \pm 25.92$ & $24.39 \pm 13.50$ & NS & NS & NS \\
\hline \multicolumn{7}{|l|}{$\mathrm{CD} 4^{+} \mathrm{FoxP} 3$} \\
\hline$\%^{4}$ & $4.56 \pm 4.73$ & $5.19 \pm 6.69$ & $5.012 \pm 4.68$ & NS & NS & NS \\
\hline A. $\operatorname{count}^{\#}$ & $75.25 \pm 82.62$ & $59.45 \pm 72.83$ & $62.62 \pm 105.0$ & NS & NS & NS \\
\hline \multicolumn{7}{|c|}{$\mathrm{CD}^{+}{ }^{+} \mathrm{CD} 25^{+}$FoxP 3} \\
\hline$\%^{4}$ & $1.12 \pm 2.09$ & $1.10 \pm 0.90$ & $0.90 \pm 0.63$ & NS & NS & NS \\
\hline A. count ${ }^{\#}$ & $19.12 \pm 42.33$ & $13.19 \pm 10.79$ & $10.21 \pm 13.65$ & NS & NS & NS \\
\hline \multicolumn{7}{|c|}{$\mathrm{CD} 4^{+} \mathrm{CD} 25^{\text {high }}$ FoxP3 } \\
\hline$\%^{4}$ & $0.27 \pm 0.34$ & $0.36 \pm 0.31$ & $0.35 \pm 0.27$ & NS & NS & NS \\
\hline A. count ${ }^{\#}$ & $4.45 \pm 6.9$ & $4.039 \pm 2.91$ & $3.26 \pm 2.81$ & NS & NS & NS \\
\hline \multicolumn{7}{|c|}{$\mathrm{CD} 4^{+} \mathrm{CD} 25^{\text {low }} \mathrm{FoxP} 3$} \\
\hline$\%^{4}$ & $0.84 \pm 1.75$ & $0.78 \pm 0.73$ & $0.57 \pm 0.51$ & NS & NS & NS \\
\hline A. count ${ }^{\#}$ & $14.57 \pm 35.46$ & $9.64 \pm 9.612$ & $6.71 \pm 12.78$ & NS & 0.017 & NS \\
\hline \multicolumn{7}{|l|}{ Th17 } \\
\hline$\%^{4}$ & $2.08 \pm 1.31$ & $0.85 \pm 1.08$ & $1.51 \pm 2.89$ & 0.0003 & 0.004 & NS \\
\hline A. count ${ }^{\#}$ & $34.44 \pm 21.02$ & $9.12 \pm 10.89$ & $10.89 \pm 22.71$ & $<0.0001$ & $<0.0001$ & NS \\
\hline
\end{tabular}

${ }^{1}$ I group: healthy controls; ${ }^{2}$ II group: pSS patients without anti-SSA/SSB; ${ }^{3}$ III group: pSS patients with anti-SSA and/or anti-SSB; $\%{ }^{4}$ : proportion of all CD $4{ }^{+}$ lymphocytes; A. count ${ }^{\#}$ : absolute count of cells in $1 \mu \mathrm{L}$ of blood. ${ }^{*}$ Mann-Whitney test. NS: not significant.

amount of $\mathrm{CD}^{+}{ }^{+} \mathrm{T}$ lymphocytes in the peripheral blood of pSS patients is also confirmed by other authors [17]. In some pSS patients, low counts of $\mathrm{CD} 4^{+}$lymphocytes or their dysfunction in peripheral blood maybe due to anti-CD4 antibodies. These autoantibodies in some pSS patients' serum were identified by Henriksson and colleagues [18]. The fact is that the proportion of $\mathrm{CD}^{+}$was lower only in our pSS patients with Abs, and no differences in proportion of $\mathrm{CD}^{+}$ and $\mathrm{CD}^{+}$in all pSS patients were observed; let us think that this lymphopenia can also be genetically determined. Apoptosis may also play a role in the pathogenesis of some extraglandular manifestations of pSS and peripheral $\mathrm{CD} 4^{+}$ lymphocytopenia $[19,20]$.

Th17 cells also appear to play a role in the development of pSS. Studies in patients with pSS and animal models of pSS have identified the presence of IL-17 in the lymphocytic infiltrates of the exocrine glands, as well as higher levels of circulating IL-17 in both serum and saliva $[8,21,22]$. On the one hand, our finding that Th17 lymphocyte counts decreased in the peripheral blood of patients with Sjögren's syndrome is quite unexpected. On the other hand, this result may be explained by the redistribution of Th17 lymphocytes, that is, increasing their concentration in tissues (salivary glands) and decreasing concentration in peripheral blood $[8,10]$. Also, we cannot dismiss presumable apoptosis of peripheral Th17 cells.

Treg lymphocytes are characterized by autoimmune reaction-inhibiting properties $[15,23]$. So they should be reduced in patients with SS [24]. However, in this study, we have not find more distinct Treg cells changes in the peripheral blood of pSS patients. No statistical significant differences were found analyzing $\mathrm{CD} 4^{+} \mathrm{CD} 25^{\text {high }} \mathrm{FoxP} 3$ cells, $\mathrm{CD} 4^{+} \mathrm{CD} 25^{\text {high }}$, or $\mathrm{CD} 4^{+} \mathrm{CD} 25^{+}$FoxP3 cells. Alike results were published by Sarigul and colleagues [25]. Sometimes it is hard to define what is what, when conflicting results have been reported. One of the problems is that different authors as Treg population define different pools of $\mathrm{CD} 4^{+}$cells. Some researchers uses two markers $\mathrm{CD} 4^{+}$and $\mathrm{CD} 25^{\text {high }}$ to identify Treg cells [26], while others also uses FoxP3 marker [15]. This is why we have checked more pools of $\mathrm{CD} 4^{+}$that some authors define as Treg cells.

The role of cytotoxic T cells in pSS pathogenesis has not been studied in detail. Autoreactive cytotoxic T cells are seen in pSS targeting autoantigens. $\mathrm{CD} 8^{+}$T-cell deficiency is a feature of many chronic autoimmune diseases, including multiple sclerosis, rheumatoid arthritis, systemic lupus erythematosus, Sjögren's syndrome, systemic sclerosis, ulcerative colitis, Crohn's disease, psoriasis, etc. It also occurs in blood of healthy relatives of patients with autoimmune diseases, suggesting that it is genetically determined. These cells play critical roles in purging acute infections, limiting persistent infections, and conferring life-long protective immunity. $\mathrm{CD}^{+} \mathrm{T}$ cell deficiency can prompt the development of chronic autoimmune diseases by impairing $\mathrm{CD}^{+} \mathrm{T}$ cell control of virus infection [27]. It is known that viral infections 

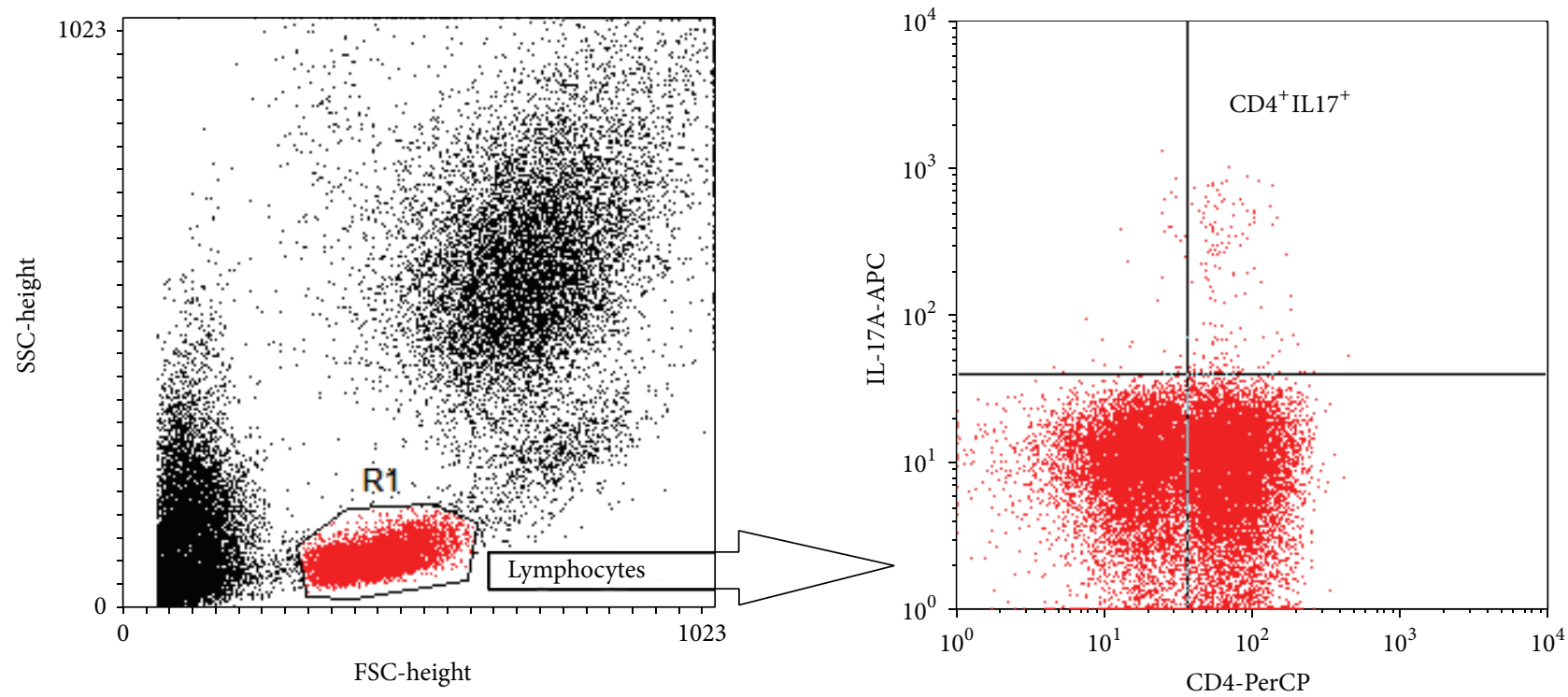

Figure 2: Representative dot plots. CD4 ${ }^{+} \mathrm{IL}-17 \mathrm{~A}^{+}$positive cells were determined on CD4-PerCP versus IL-17A-APC dot plot by gating on lymphocyte on the forward-scatter versus side-scatter dot plot.

TABLE 4: Distribution of CD8 $8^{+}$lymphocyte subpopulations in peripheral blood of pSS patients and controls.

\begin{tabular}{|c|c|c|c|c|c|c|}
\hline Patients & ${ }^{1}$ I-controls & ${ }^{2} \mathrm{II}-\mathrm{pSS} \mathrm{Abs}^{-}$ & ${ }^{3}$ III-pSS Abs ${ }^{+}$ & $\begin{array}{c}P^{*} \\
\text { I-II } \\
\end{array}$ & $\begin{array}{c}P^{*} \\
\text { I-III }\end{array}$ & $\begin{array}{c}P^{*} \\
\text { II-III }\end{array}$ \\
\hline \multicolumn{7}{|c|}{$\mathrm{CD}^{+}$lymphocyte population } \\
\hline \multicolumn{7}{|c|}{$\mathrm{CD} 8^{\text {high }} \mathrm{CD} 57^{+} \mathrm{CD} 27^{+}$} \\
\hline$\%^{4}$ & $5.306 \pm 3.899$ & $5.329 \pm 5.431$ & $8.239 \pm 8.239$ & NS & NS & 0.032 \\
\hline A. count ${ }^{\#}$ & $34.26 \pm 29.11$ & $27.05 \pm 33.57$ & $42.59 \pm 33.12$ & NS & NS & 0.011 \\
\hline \multicolumn{7}{|c|}{$\mathrm{CD} 8^{\text {high }} \mathrm{CD} 57^{+} \mathrm{CD} 27^{-}$} \\
\hline$\%^{4}$ & $22.67 \pm 13.33$ & $25.52 \pm 17.42$ & $27.40 \pm 19.55$ & NS & NS & NS \\
\hline A. count ${ }^{\#}$ & $150.6 \pm 119.7$ & $143.4 \pm 157.7$ & $155.2 \pm 136.8$ & NS & NS & NS \\
\hline \multicolumn{7}{|c|}{$\mathrm{CD} 8^{\text {high }} \mathrm{CD} 57^{-} \mathrm{CD} 27^{+}$} \\
\hline$\%^{4}$ & $59.13 \pm 17.54$ & $46.51 \pm 22.00$ & $47.16 \pm 22.29$ & 0.026 & NS & NS \\
\hline A. count ${ }^{\#}$ & $387.3 \pm 211.4$ & $227.9 \pm 186.6$ & $224.8 \pm 129.3$ & 0.0003 & 0.005 & NS \\
\hline \multicolumn{7}{|c|}{$\mathrm{CD} 8^{\text {high }} \mathrm{CD} 57^{-} \mathrm{CD} 27^{-}$} \\
\hline$\%^{4}$ & $13.10 \pm 8.112$ & $22.60 \pm 15.37$ & $17.18 \pm 11.20$ & 0.024 & NS & NS \\
\hline A. count ${ }^{\#}$ & $85.79 \pm 73.99$ & $119.1 \pm 126.7$ & $99.46 \pm 85.96$ & NS & NS & NS \\
\hline \multicolumn{7}{|l|}{$\mathrm{CD}^{+}$FoxP3 } \\
\hline$\%^{5}$ & $10.59 \pm 15.16$ & $5.881 \pm 6.673$ & $6.498 \pm 7.939$ & NS & NS & NS \\
\hline A. count ${ }^{\#}$ & $91.42 \pm 126.1$ & $51.19 \pm 86.72$ & $50.49 \pm 60.37$ & NS & NS & NS \\
\hline
\end{tabular}

${ }^{1}$ I group: healthy controls; ${ }^{2}$ II group: pSS patients without anti-SSA/SSB; ${ }^{3}$ III group: pSS patients with anti-SSA and/or anti-SSB; $\%{ }^{4}:$ proportion of all CD 8 high lymphocytes; $\%^{5}$ : proportion of all CD8 ${ }^{+}$lymphocytes. A. count ${ }^{*}$ : absolute count of cells in $1 \mu \mathrm{L}$ of blood. ${ }^{*}$ Mann-Whitney test. NS: not significant.

are the best candidates for the role of environmental triggers to autoimmune reactions [28]. It is proposed that, after activation in peripheral lymphoid organs by cross-reacting foreign antigens, autoreactive $\mathrm{T}$ cells enter the target organ where they are reactivated by B cells which provide costimulatory survival signals, thereby inhibiting the activation-induced T-cell apoptosis which normally occurs when autoreactive $\mathrm{T}$ cells enter the target organ [27]. Understanding $\mathrm{CD} 8^{+} \mathrm{T}$ memory effector cells differentiation is essential for studying how virus-specific $\mathrm{CD}^{+} \mathrm{T}$ cells control viral infection.
Distinct stages of virus-specific $\mathrm{CD}^{+} \mathrm{T}$ memory effector cells differentiation have been extensively characterized by phenotypic and functional analyses. Primed virus-specific $\mathrm{CD}^{+} \mathrm{T}$ cells typically differentiate from the least mature memory stage $\left(\mathrm{CD} 27^{+}\right)$to the most mature effector stage when they start to lose CD27 and obtain CD57 marker and eventually become terminally differentiated effector cells which can be further defined by CD57 expression [29]. According to some studies, last stage of $\mathrm{CD}^{+}$cells differentiation seems to be $\mathrm{CD} 8^{+} \mathrm{CD} 27^{-} \mathrm{CD} 57^{-} \mathrm{T}$ cells subset with 
high perforin and killing activity. Is this the true end-stage or terminally-differentiated state of cytotoxic T cells? This fact is still unclear [30]. We observed increased proportion of this population in pSS patients, but significant differences were observed only in pSS without Abs group. In pSS with Abs group, negative correlation between $\mathrm{CD} 8{ }^{\text {high }} \mathrm{CD} 27^{-} \mathrm{CD} 57^{-}$ T cells subset absolute count and Schirmer's $I$ test results was observed. This connection proposes that this subset can be involved in a pathogenic process which appears in the glandular tissue. Impaired proportion and absolute counts of $\mathrm{CD} 8{ }^{\text {high }} \mathrm{CD} 27^{+} \mathrm{CD} 57^{-} \mathrm{T}$ cells in blood of pSS patients can be the reason of lower counts of $\mathrm{CD}^{+}$in blood of pSS patients. It is not known whether the proportion and absolute counts of this population are downregulated in blood by migration to inflammatory sites, or this can be due to increased apoptosis of these cells. There is hypothesis that more mature effector stage $\left(\mathrm{CD} 8{ }^{\text {high }} \mathrm{CD} 27^{+} \mathrm{CD} 57^{+}\right.$and $\mathrm{CD} 8^{\text {high }} \mathrm{CD} 27^{-} \mathrm{CD} 57^{+}$) cells with lower capacity of proliferation are more resistant to apoptosis than least mature memory stage $\mathrm{CD} 8{ }^{\text {high }} \mathrm{CD} 27^{+} \mathrm{CD} 57^{-} \mathrm{T}$ cells [29-31]. All these observed changes in $\mathrm{CD}^{+} \mathrm{T}$ cell subpopulations rearrangement prove that these subpopulations actively participate in pathological processes of pSS.

NKT lymphocytes and NK cells might function as regulatory $\mathrm{T}$ cells and are one of the autoimmune process preventing chains $[32,33]$. According to literature, in patients with autoimmune rheumatic diseases, the decreased NKT and NK cell counts and functional characteristics are associated with the progression of autoimmune process and autoantibody production [34-37]. Nevertheless Szodoray et al. published results where they identified higher proportion of these cells in blood of pSS patients than in control group [38]. Our investigation of these populations showed a significant decrease of NKT and NK-cell absolute counts in the peripheral blood of pSS patients with Abs; however, the fact that a proportion of these cells were similar with the controls can indicate that lower absolute counts can be due to genetically determined lymphopenia. There is also possibility that low counts of these cell populations in periphery can be by reason of overall lymphocyte population migration to inflammatory sites or/and apoptosis.

In conjunction with the classical $\mathrm{CD}^{+}$Tregs, we were also investigating $\mathrm{CD}^{+}$suppressor cells that express FoxP3 marker, as FoxP3 confers suppressive properties and is confined to regulatory $\mathrm{T}$ cells. $\mathrm{CD} 8^{+}$FoxP3 cells represent a new regulatory population and ability of these $\mathrm{CD} 8^{+}$FoxP3 Treg to suppress $\mathrm{CD} 8^{+}$responses far more effectively than CD $4^{+}$FoxP3 Treg [39]. This was shown in mice after experimental allogeneic bone marrow transplantation. Our study results did not show any significant differences in proportion or absolute count changes on these cells in pSS patients' peripheral blood in comparison to healthy controls.

We found negative correlation between BAFF and $\mathrm{T}$ and $B$ cells in pSS patients without Abs. Increase of BAFF in serum can be due to negative regulation of BAFF secretion by monocytes [40]. This fact can indicate tight control of BAFF secretion. Whereas we do not found correlation between BAFF and lymphocyte populations changes in pSS patients with Abs group, what can be the indication of uncontrolled BAFF secretion and its homeostasis disturbance?

Despite recent knowledge, in many respects, the role of $\mathrm{T}$ cells and their subsets in pSS remains unexplained. Are cells in the infiltrate specific, or maybe many of them are just bystanders (with nonactivated phenotype) recruited from the periphery to the inflammatory sites? $\mathrm{T}$ cells undergo expansion within the gland, or does this occur elsewhere with subsequent migration? Is there migration in and out of the gland, or do T cells remain in the infiltrates once they arrive? Pointers to these questions could help us understand which processes are going on periphery. All this together could help us to understand pathogenesis of the primary SS.

One of future projects should be the immunohistochemistry for assessing cell populations' changes in salivary glands in parallel with blood analysis and apoptosis markers. Such analysis could help better to define changes of cell populations in periphery, is this due migration to the inflammatory sites or increased apoptosis, or maybe both.

\section{Conflict of Interests}

The authors declare that they have no conflict of interests.

\section{Acknowledgment}

This research was funded by a Grant no. LIG-23/2010 from the Research Council of Lithuania.

\section{References}

[1] J.-O. Pers, C. Daridon, V. Devauchelle et al., "BAFF overexpression is associated with autoantibody production in autoimmune diseases," Annals of the New York Academy of Sciences, vol. 1050, pp. 34-39, 2005.

[2] C. Vitali, S. Bombardieri, R. Jonsson et al., "Classification criteria for Sjögren's syndrome: a revised version of the European criteria proposed by the American-European Consensus Group," Annals of the Rheumatic Diseases, vol. 61, no. 6, pp. 554558, 2002.

[3] S. Candon, J. E. Gottenberg, D. Bengoufa, L. Chatenoud, and X. Mariette, "Quantitative assessment of antibodies to ribonucleoproteins in primary Sjögren syndrome: correlation with Bcell biomarkers and disease activity," Annals of the Rheumatic Diseases, vol. 68, no. 7, pp. 1208-1212, 2009.

[4] J.-E. Gottenberg, M. Busson, J. Cohen-Solal et al., "Correlation of serum B lymphocyte stimulator and $\beta 2$ microglobulin with autoantibody secretion and systemic involvement in primary Sjogren's syndrome," Annals of the Rheumatic Diseases, vol. 64, no. 7, pp. 1050-1055, 2005.

[5] G. Sudzius, D. Mieliauskaite, A. Siaurys et al., "Could the complement component $\mathrm{C} 4$ or its fragment $\mathrm{C} 4 \mathrm{~d}$ be a marker of the more severe conditions in patients with primary Sjögren's syndrome?" Rheumatology International, vol. 34, no. 2, pp. 235241, 2014.

[6] J.-E. Gottenberg, F. Aucouturier, J. Goetz et al., "Serum immunoglobulin free light chain assessment in rheumatoid arthritis and primary Sjögren's syndrome," Annals of the Rheumatic Diseases, vol. 66, no. 1, pp. 23-27, 2007. 
[7] J.-E. Gottenberg, R. Seror, C. Miceli-Richard et al., "Serum levels of beta2-microglobulin and free light chains of immunoglobulins are associated with systemic disease activity in primary sjögren's syndrome. Data at enrollment in the prospective ASSESS cohort," PLoS ONE, vol. 8, no. 5, Article ID e59868, 2013.

[8] A. Sakai, Y. Sugawara, T. Kuroishi, T. Sasano, and S. Sugawara, "Identification of IL-18 and Th17 cells in salivary glands of patients with Sjögren's syndrome, and amplification of IL-17mediated secretion of inflammatory cytokines from salivary gland cells by IL-18," Journal of Immunology, vol. 181, no. 4, pp. 2898-2906, 2008.

[9] H. Z. Low and T. Witte, "Aspects of innate immunity in Sjögren's syndrome," Arthritis Research and Therapy, vol. 13, no. 3, article 218, 2011.

[10] G. Sudzius, D. Mieliauskaite, I. Butrimiene, A. Siaurys, Z. Mackiewicz, and I. Dumalakiene, "Activity of T-helper cells in patients with primary Sjögren's syndrome," In Vivo, vol. 27, no. 2, pp. 263-268, 2013.

[11] D. M. Gravano and K. K. Hoyer, "Promotion and prevention of autoimmune disease by CD8+ T cells," Journal of Autoimmunity, vol. 45, pp. 68-79, 2013.

[12] W. A. Goodman, K. D. Cooper, and T. S. McCormick, "Regulation generation: the suppressive functions of human regulatory T cells," Critical Reviews in Immunology, vol. 32, no. 1, pp. 65-79, 2012.

[13] R. Seror, P. Ravaud, S. J. Bowman et al., “EULAR Sjögren's syndrome disease activity index: development of a consensus systemic disease activity index for primary Sjögren's syndrome," Annals of the Rheumatic Diseases, vol. 69, no. 6, pp. 1103-1109, 2010.

[14] R. Seror, P. Ravaud, X. Mariette et al., "EULAR Sjögren's Syndrome Patient Reported Index (ESSPRI): development of a consensus patient index for primary Sjögren's syndrome," Annals of the Rheumatic Diseases, vol. 70, no. 6, pp. 968-972, 2011.

[15] M. I. Christodoulou, E. K. Kapsogeorgou, N. M. Moutsopoulos, and H. M. Moutsopoulos, "Foxp3 ${ }^{+}$T-regulatory cells in Sjögren's syndrome: correlation with the grade of the autoimmune lesion and certain adverse prognostic factors," The American Journal of Pathology, vol. 173, no. 5, pp. 1389-1396, 2008.

[16] M. I. Christodoulou, E. K. Kapsogeorgou, and H. M. Moutsopoulos, "Characteristics of the minor salivary gland infiltrates in Sjögren's syndrome," Journal of Autoimmunity, vol. 34, no. 4, pp. 400-407, 2010.

[17] T. Mandl, A. Bredberg, L. T. H. Jacobsson, R. Manthorpe, and G. Henriksson, "CD4+ T-lymphocytopenia-a frequent finding in anti-SSA antibody seropositive patients with primary Sjögren's syndrome," Journal of Rheumatology, vol. 31, no. 4, pp. 726-728, 2004.

[18] G. Henriksson, R. Manthorpe, and A. Bredberg, "Antibodies to CD4 in primary Sjogren's syndrome," Rheumatology, vol. 39, no. 2, pp. 142-147, 2000.

[19] P. Manganelli and P. Fietta, "Apoptosis and Sjögren syndrome," Seminars in Arthritis and Rheumatism, vol. 33, no. 1, pp. 49-65, 2003.

[20] Y. Ichikawa, K. Arimori, M. Yoshida et al., "Abnormal expression of apoptosis-related antigens, Fas and bcl-2, on circulating T-lymphocytes subsets in primary Sjogren's syndrome," Clinical and Experimental Rheumatology, vol. 13, no. 3, pp. 307-313, 1995.

[21] C. Q. Nguyen, M. H. Hu, Y. Li, C. Stewart, and A. B. Peck, "Salivary gland tissue expression of interleukin-23 and interleukin-17 in Sjögren's syndrome: findings in humans and mice," Arthritis and Rheumatism, vol. 58, no. 3, pp. 734-743, 2008.

[22] D. Mieliauskaite, I. Dumalakiene, R. Rugiene, and Z. MacKiewicz, "Expression of IL-17, IL-23 and their receptors in minor salivary glands of patients with primary Sjögren's syndrome," Clinical and Developmental Immunology, vol. 2012, Article ID 187258, 8 pages, 2012.

[23] J. M. Fletcher, R. Lonergan, L. Costelloe et al., "CD39 ${ }^{+}$Foxp $3^{+}$ regulatory $\mathrm{T}$ cells suppress pathogenic Thl7 cells and are impaired in multiple sclerosis," Journal of Immunology, vol. 183, no. 11, pp. 7602-7610, 2009.

[24] X. Li, L. Qian, G. Wang et al., "T regulatory cells are markedly diminished in diseased salivary glands of patients with primary Sjögren's syndrome," Journal of Rheumatology, vol. 34, no. 12, pp. 2438-2445, 2007.

[25] M. Sarigul, V. Yazisiz, C. I. Başsorgun et al., "The numbers of Foxp3+ Treg cells are positively correlated with higher grade of infiltration at the salivary glands in primary Sjögren's syndrome," Lupus, vol. 19, no. 2, pp. 138-145, 2010.

[26] J.-E. Gottenberg, F. Lavie, K. Abbed et al., "CD4 CD25 high regulatory $\mathrm{T}$ cells are not impaired in patients with primary Sjögren's syndrome," Journal of Autoimmunity, vol. 24, no. 3, pp. 235-242, 2005.

[27] M. P. Pender, "CD8+ T-cell deficiency, epstein-barr virus infection, vitamin d deficiency, and steps to autoimmunity: a unifying hypothesis," Autoimmune Diseases, vol. 2012, Article ID 189096, 16 pages, 2012.

[28] N. V. Sipsas, M. N. Gamaletsou, and H. M. Moutsopoulos, "Is Sjögren's syndrome a retroviral disease?" Arthritis Research and Therapy, vol. 13, no. 2, article 212, 2011.

[29] A. Hoji, N. C. Connolly, W. G. Buchanan, and C. R. Rinaldo Jr., "CD27 and CD57 expression reveals atypical differentiation of human immunodeficiency virus type 1-specific memory $\mathrm{CD}^{+}$ T cells," Clinical and Vaccine Immunology, vol. 14, no. 1, pp. 7480, 2007.

[30] R. C. Wu, P. Hwu, and L. G. Radvanyi, "New insights on the role of $\mathrm{CD}^{+} \mathrm{CD}^{+} 7^{+}$T-cells in cancer," OncoImmunology, vol. 1, no. 6, pp. 954-956, 2012.

[31] M. Strioga, V. Pasukoniene, and D. Characiejus, "CD8 ${ }^{+} \mathrm{CD} 28^{-}$ and $\mathrm{CD} 8^{+} \mathrm{CD} 57^{+} \mathrm{T}$ cells and their role in health and disease," Immunology, vol. 134, no. 1, pp. 17-32, 2011.

[32] M. Polihronis, N. I. Tapinos, S. E. Theocharis, A. Economou, C. Kittas, and H. M. Moutsopoulos, "Modes of epithelial cell death and repair in Sjogren's syndrome (SS)," Clinical and Experimental Immunology, vol. 114, no. 3, pp. 485-490, 1998.

[33] A. Lurati, L. Bertani, M. Marrazza, K. A. Re, D. Bompane, and M. Scarpellini, "NK cell count as predictor of clinical response in patients with rheumatoid arthritis treated with rituximab," Biologics: Targets \& Therapy, vol. 6, pp. 83-87, 2012.

[34] N. J. Struyf, H. W. Snoeck, C. H. Bridts, L. S. de Clerck, and W. J. Stevens, "Natural killer cell activity in Sjogren's syndrome and systemic lupus erythematosus: stimulation with interferons and interleukin-2 and correlation with immune complexes," Annals of the Rheumatic Diseases, vol. 49, no. 9, pp. 690-693, 1990.

[35] M. R. J. Green, A. S. M. Kennell, M. J. Larche, M. H. Seifert, D. A. Isenberg, and M. R. Salaman, "Natural killer cell activity in families of patients with systemic lupus erythematosus: demonstration of a killing defect in patients," Clinical and Experimental Immunology, vol. 141, no. 1, pp. 165-173, 2005. 
[36] S. Kojo, Y. Adachi, H. Keino, M. Taniguchi, and T. Sumida, "Dysfunction of T cell receptor AV24AJ18+, BV11+ doublenegative regulatory natural killer $\mathrm{T}$ cells in autoimmune diseases," Arthritis \& Rheumatism, vol. 44, no. 5, pp. 1127-1138, 2001.

[37] J. Wither, Y.-C. Cai, S. Lim et al., "Reduced proportions of natural killer $\mathrm{T}$ cells are present in the relatives of lupus patients and are associated with autoimmunity," Arthritis Research and Therapy, vol. 10, no. 5, article R108, 2008.

[38] P. Szodoray, G. Papp, I. F. Horvath et al., "Cells with regulatory function of the innate and adaptive immune system in primary Sjögren's syndrome," Clinical and Experimental Immunology, vol. 157, no. 3, pp. 343-349, 2009.

[39] R. J. Robb, K. E. Lineburg, R. D. Kuns et al., "Identification and expansion of highly suppressive $\mathrm{CD} 8^{+} \mathrm{FoxP}^{+}$regulatory $\mathrm{T}$ cells after experimental allogeneic bone marrow transplantation," Blood, vol. 119, no. 24, pp. 5898-5908, 2012.

[40] F. Lavie, C. Miceli-Richard, M. Ittah, J. Sellam, J.-E. Gottenberg, and X. Mariette, "Increase of B cell-activating factor of the TNF family (BAFF) after rituximab treatment: insights into a new regulating system of BAFF production," Annals of the Rheumatic Diseases, vol. 66, no. 5, pp. 700-703, 2007. 


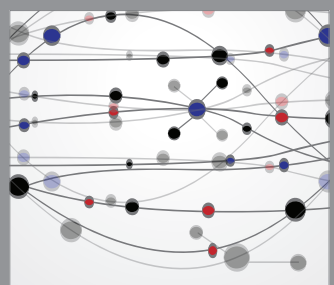

The Scientific World Journal
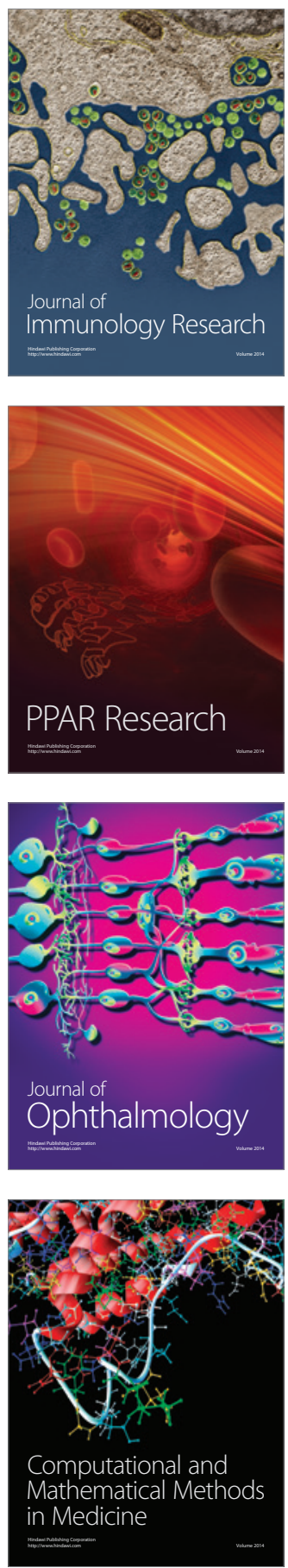

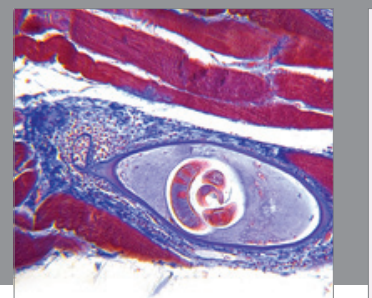

Gastroenterology

Research and Practice
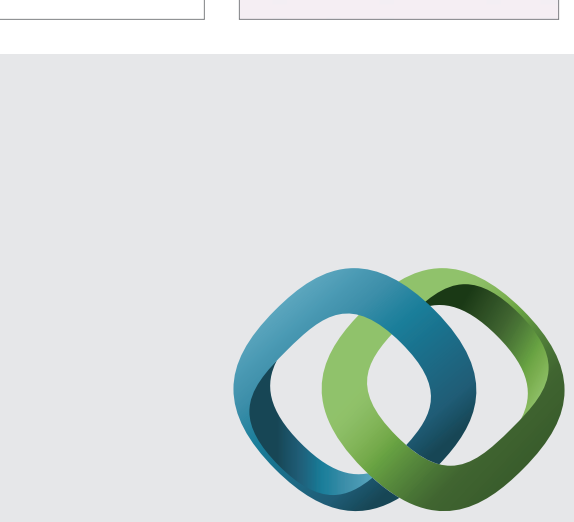

\section{Hindawi}

Submit your manuscripts at

http://www.hindawi.com
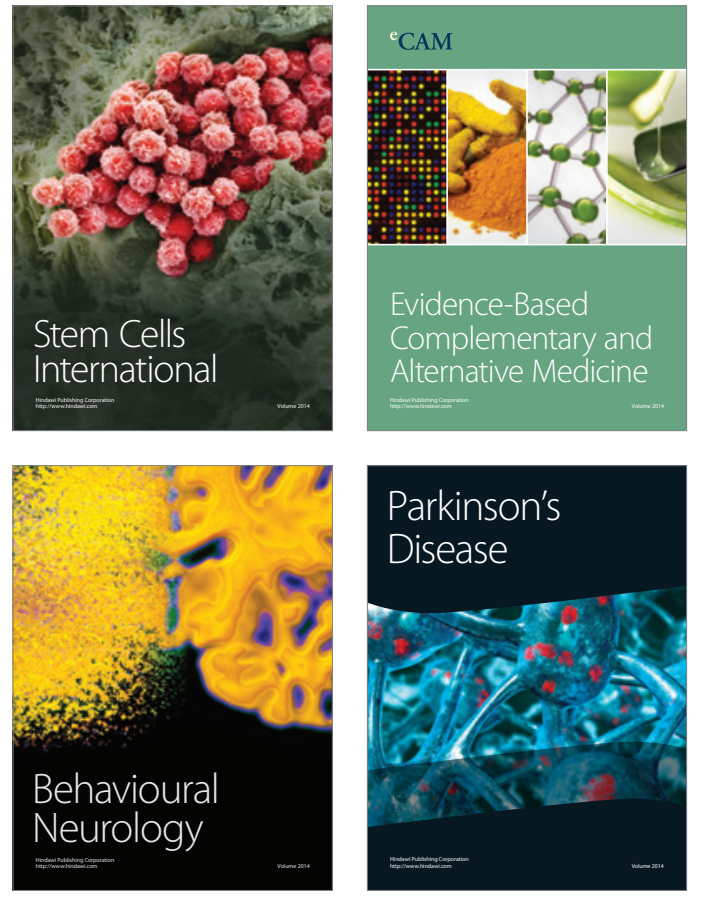
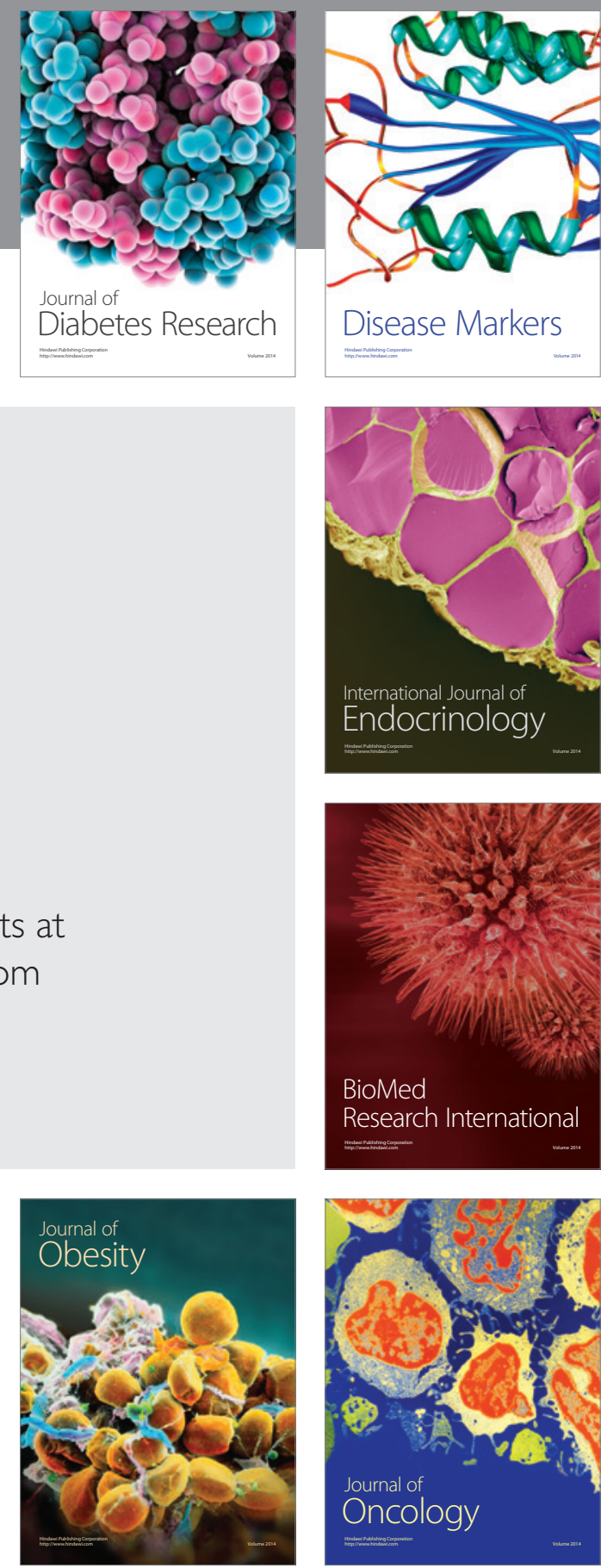

Disease Markers
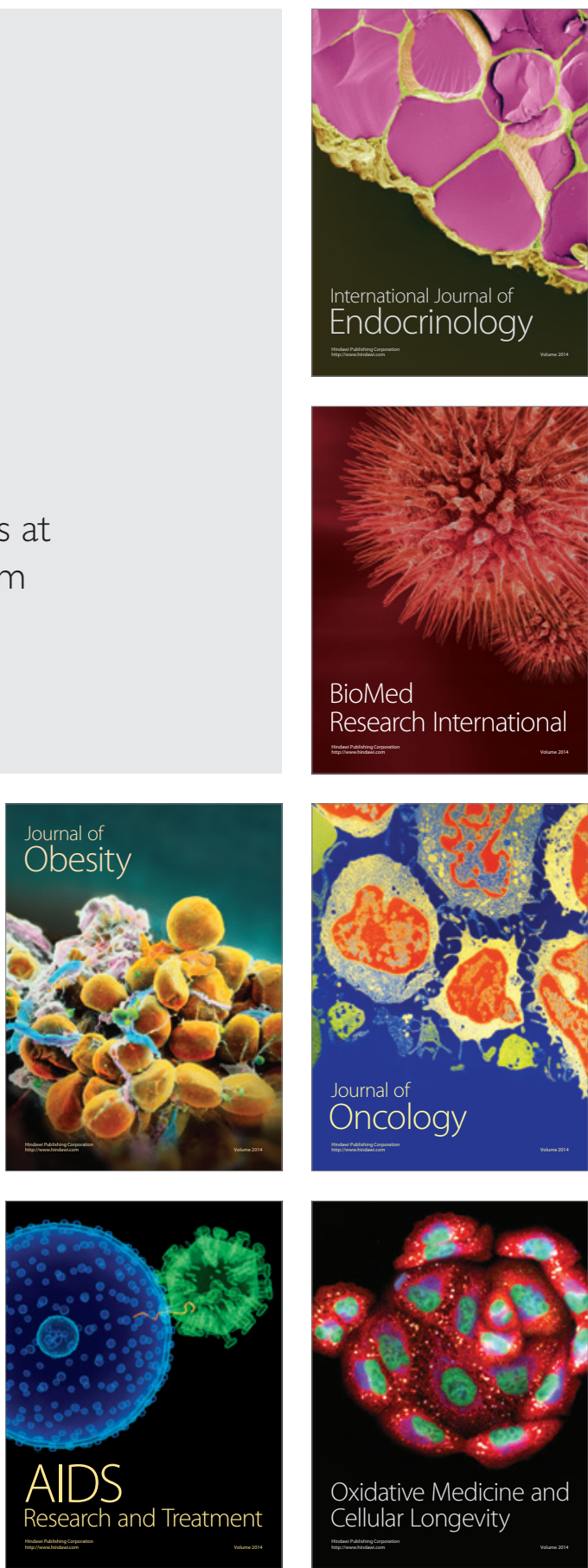